Int. J. Electrochem. Sci., 11 (2016) 10779 - 10794

Short Communication

\title{
Preparation and Phosphating of Yttrium-Based Chemical Conversion Coatings on AZ91D Magnesium Alloy for Corrosion Protection
}

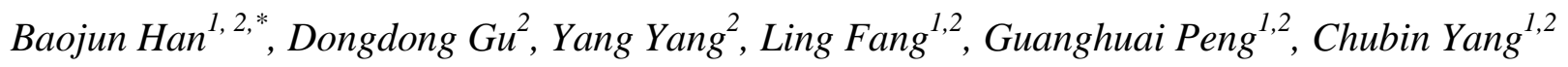 \\ ${ }^{1}$ Jiangxi Provincial Engineering Research Center for Magnesium alloys, GanNan Normal University, \\ Ganzhou 341000, PR China \\ ${ }^{2}$ School of Chemistry and Chemical Engineering, GanNan Normal University, Ganzhou 341000, PR \\ China \\ *Email: baojunhan@126.com
}

doi: $10.20964 / 2016.12 .97$

Received: 2 September 2016 / Accepted: 23 October 2016 / Published: 10 November 2016

The yttrium-based chemical conversion coatings were prepared on AZ91D magnesium alloy by immersing in yttrium nitrate solution firstly, and then in ammonium dihydrogen phosphate $\left(\mathrm{NH}_{4} \mathrm{H}_{2} \mathrm{PO}_{4}\right)$ solution. The micro-morphology and the composition of the coating were investigated using scanning electron microscopy (SEM), energy dispersive spectroscopy (EDS), X-ray diffraction (XRD) and X-ray photoelectron spectroscopy (XPS), respectively. The results show that the number and size of the cracks in the coating were obviously reduced after phosphating, and the compactness of the yttrium conversion coatings were increased. The phosphated coating was mainly composed of $\mathrm{Y}_{2} \mathrm{O}_{3}, \mathrm{YO}_{\mathrm{x} / \mathrm{y}}, \mathrm{Mg}_{3}\left(\mathrm{PO}_{4}\right)_{2}, \mathrm{AlPO}_{4}$ and $\mathrm{YPO}_{4}$. Furthermore, the corrosion resistance of the coating was measured by means of potentiodynamic polarization curves and electrochemical impedance spectroscopy (EIS). Following phosphating, the corrosion potential of the coating was shifted positively about $180 \mathrm{mV}$ compared to the uncoated one, and the corrosion current density decreased about one order of magnitude.

Keywords: AZ91D magnesium alloy; yttrium-based conversion coating; phosphating; corrosion resistance

\section{FULL TEXT}

(C) 2016 The Authors. Published by ESG (www.electrochemsci.org). This article is an open access article distributed under the terms and conditions of the Creative Commons Attribution license (http://creativecommons.org/licenses/by/4.0/). 